Article

\title{
Quantitative Mineralogical Comparison between HPGR and Ball Mill Products of a Sn-Ta Ore
}

\author{
Sarbast Ahmad Hamid ${ }^{1, *(1)}$, Pura Alfonso ${ }^{1}$ (D), Hernan Anticoi ${ }^{1}$ (i), Eduard Guasch ${ }^{1}$ (D), \\ Josep Oliva ${ }^{1}$, Marek Dosbaba ${ }^{2}$, Maite Garcia-Valles ${ }^{3}$ (i) and Marina Chugunova ${ }^{1}$ \\ 1 Departament d'Enginyeria Minera, Industrial i TIC, Universitat Politècnica de Catalunya Barcelona Tech, \\ Av. Bases de Manresa 61-63, Manresa, 08242 Barcelona, Spain; maria.pura.alfonso@upc.edu (P.A.); \\ hernan.anticoi@upc.edu (H.A.); eduard.guasch@upc.edu (E.G.); josep.oliva@upc.edu (J.O.); \\ marina.chugunova1@upc.edu (M.C.) \\ 2 TESCAN, Libušina tř. 21, 62300 Brno, Czech Republic; marek.dosbabai@tescan.com \\ 3 Departament de Mineralogia, Petrologia i Geologia Aplicada, Universitat de Barcelona, \\ Carrer Martí i Franquès, s/n, 08028 Barcelona, Spain; maitegarciavalles@ub.edu \\ * Correspondence: sarbast.hamid@upc.edu; Tel.: +34-938-777244
}

Received: 16 February 2018; Accepted: 5 April 2018; Published: 11 April 2018

\begin{abstract}
The mineralogy and liberation characteristics of the comminuted Penouta leucogranite host of the $\mathrm{Sn}$-Ta ore were determined. Grinding developed by a combination of high-pressure grinding rolls (HPGR) followed by a ball mill (BM) was compared with a single ball mill process. The mineral characteristics of the grinding products were analyzed using a Tescan Integrated Mineralogical Analyzer (TIMA-X) and X-ray powder diffraction (XRD). The ore contains $103 \mathrm{ppm}$ of Ta and is mainly composed of quartz, albite, microcline, muscovite, and kaolinite. $\mathrm{Nb}$, Ta-rich minerals are columbite-(Mn) and tantalite-(Mn), as well as minor microlite and wodginite. The liberation in the product is high in the size fraction of less than $250 \mu \mathrm{m}$ (51-52 $\mathrm{wt} \%$ for columbite-group minerals (CGM) and 74-80 wt \% for cassiterite) and reduced in larger particles (8.8-17 wt \% for CGM and $28-37$ wt \% for cassiterite). The recovery in the $-250 \mu \mathrm{m}$ fraction was high, while in the larger fraction it is limited, remaining up to $80 \mathrm{ppm}$ in some tailings. The combined use of HPGR and a $\mathrm{BM}$ reduces the particle size distribution of the product and, thus, increases the liberation of the ores. Smaller fractions can be treated directly using gravity methods; however, particles of a size greater than $+250 \mu \mathrm{m}$ should be ground more.
\end{abstract}

Keywords: tantalum; liberation; process mineralogy; grinding; high-pressure grinding rolls; ball mill

\section{Introduction}

Tantalum has a great relevance nowadays for its use in modern technologies, is difficult to substitute using other metals [1], and is considered a critical metal [2-5]. Europe needs to have greater self-sufficiency in the exploitation of strategic metals; for this reason, the exploitation of low-grade deposits should be considered. This is the case with the tantalum ore deposits in Europe. Tantalum deposits are mainly pegmatites and rare metal granites [6]. In general, low-grade tantalum ore deposits in rare metal granites are relatively abundant in the western part of Europe. However, in order to make the exploitation of these deposits economically viable, their processing needs to be optimized. To this end, it is crucial to know the mineralogical and textural characteristics of the ores in order to be able to carry out their liberation in the most efficient way. 
The selection of the comminution mechanisms is very important in the ore processing and, thus, this process consumes between $65 \%$ and $68.5 \%$ of all the energy used for processing [7]. The use of high-pressure grinding rolls (HPGR) followed by a ball mill (BM) can represent a significant increase in circuit capacity and energy savings [8-10].

The mineral chemistry of Ta-bearing minerals is important to establish ore processing. Tantalum occurs in a variety of oxide minerals, usually as a solid solution with niobium. In addition, some radioactive elements, such as thorium and uranium, can be present [11] in substitution of $\mathrm{Nb}$ and Ta, or as mineral impurities. Texture is a fundamental characteristic of ore that will determine the mineral separation $[12,13]$. The particle shapes have a direct influence on the interactions of the mineral with the media during processing [14], and the mineral liberation size is a determining parameter to determine the comminution process during mineral processing. In addition, knowing what minerals accompany the ore represents valuable information for applying separation techniques. The first study for predicting the natural liberation spectrum was conducted by Gaudin [15]. Since then, many liberation models have been established based on the analysis of the mineral texture and mineralogy that accompany the ore of interest [16-18]. In these models, the texture of an ore is simplified and characterized in such a way that the liberation distribution of the particles can be predicted as a function of the size [19].

The use of automated techniques to determine the process mineralogy provides an important tool to determine the liberation degree of ore [20-24]. The main advantage is the determination of a large number of particles that are important for statistical results and reduction of human error [25]. However, the correct interpretation of automated mineralogy data requires a mineralogical understanding of the material [26], and must usually be used in conjunction with other mineralogical techniques, e.g., this technique does not distinguish between polymorph minerals. Another problem is the difficulty in obtaining a representative sample to analyze [27]. A previous mineral knowledge of the sample is necessary to obtain good results. This is especially important for minerals that form solid solutions, such as $\mathrm{Nb}$-Ta oxides, or those with lithium or hydroxyl groups. The use of scanning electron microscopy (SEM) and an electron microprobe analyzer (EMPA) can be decisive in predicting the minerals present in the sample. Additional problems can be derived from sample preparation; this needs to prevent the agglomeration of particles so that automated mineralogy techniques do not consider it as a single particle [28]. Moreover, some stereological errors are made with the use of mineralogical techniques based on the analysis of polished sections [29,30]; however, several methods were proposed to introduce a correction or provide suggestions for making the estimation [31].

The aim of this work was to characterize the ground products for low-grade tantalum ore and to compare the liberation degrees of two different milling procedures to determine the best option to optimize mineral processing operations. The grinding procedures include HPGR and BM devices.

\section{Study Area}

The Penouta ore deposit is located in Penouta village, in the municipality of Viana do Bolo, Ourense, Galicia, northeast of Spain. It is a Sn-Ta greisen-type ore deposit, where mineralization occurs in quartz veins related to the greisen and in the surrounding leucogranites. The Penouta leucogranite is hosted in metamorphic rocks, mainly constituted by gneisses and mica-schists corresponding to the Viana do Bolo series. This deposit has been mined for Sn, and occasionally for tantalum, since Roman times. In 1983, the exploitation of the ore deposit ended due the low price of metal and the poor recovering degree of $\mathrm{Sn}$, approximately $30 \%$ of the total tin content [32]. As a result, several tailings remain close to the mine [33].

The mining interest in the area is the ancient Sn-Ta ore open pit and the ancient tailings, which still contain significant amounts of $\mathrm{Sn}$ and Ta. The mineralogy of the open pit was recently reported in ore deposit studies [33-35]. The process mineralogy study of the largest tailing is presented in this volume [36]. 


\section{Materials and Methods}

\subsection{Sample Preparation}

A representative sample of the ancient open pit of the Penouta mine was used. An initial sample of 1 ton of leucogranite was sorted, and $15 \mathrm{~kg}$ were used in the experiments. The sample, after the primary crushing by jaw crusher, was split and prepared into two parts for further crushing by either HPGR or BM, and only BM at the mines laboratory at the Polytechnic University of Catalonia. Ball mill tests were carried out in a mill with an internal diameter of $305 \mathrm{~mm}$ and a length of $305 \mathrm{~mm}$, with conditions shown in Reference [37]. A HPGR test was conducted using a unit of $25 \mathrm{~cm}$ diameter rolls and a width of $15 \mathrm{~cm}$ that was fully equipped to control and record the hydraulic pressures, which runs at 40 bar. These experiments were conducted effectively, with representative samples of the same feed being milled in each device to two target product size distributions ( 600 and $-600 \mu \mathrm{m})$. The top feed size for the units was 5-20 mm and the products from the HPGR and BM were then screened into two fractions $(+600$ and $-600 \mu \mathrm{m})$. The sample top size $(+600 \mu \mathrm{m})$ from HPGR was fed to the BM and comminuted for $10 \mathrm{~min}$. in the same way as the first ball milling. In this study, subsamples from two size fractions in the products were subjected to a shaking table to study the effect of milling on the liberation process.

Due to the low Ta content in the Penouta deposit, it had to be concentrated in order to obtain a high number of ore particles to be studied. After the sample was ground, it was sieved and fed into a laboratory scale Holman-Wilfley shaking table separation. The screened samples under $600 \mu \mathrm{m}$ were physically separated into two fractions $(-250 \mu \mathrm{m}$ and $-600+250 \mu \mathrm{m})$ in order to obtain concentrate samples. In the schematic diagram of sample preparation, (Figure 1) C1, C3, and C5 are $-250 \mu \mathrm{m}$ and C2, C4, and C6 are $-600+250 \mu \mathrm{m}$.

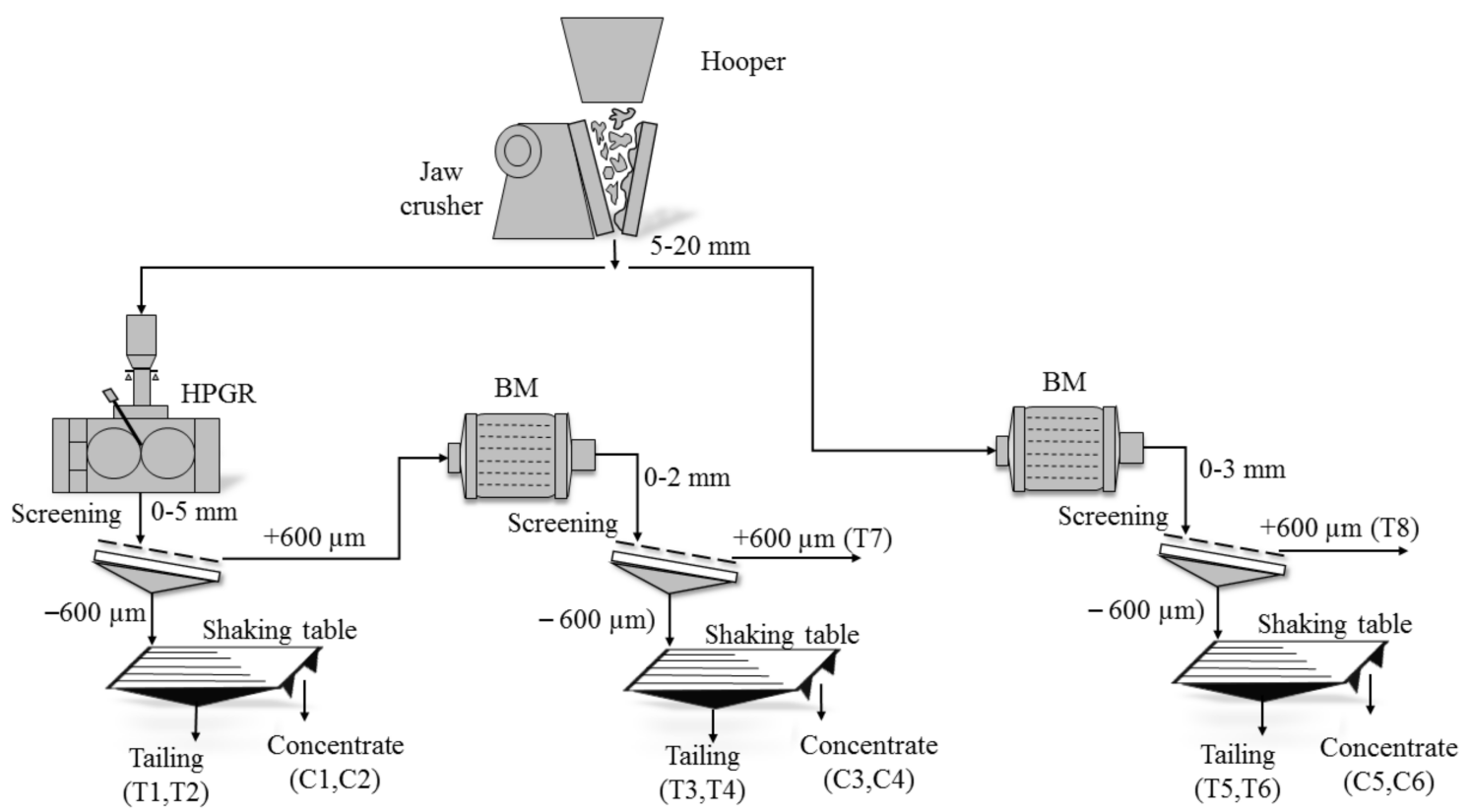

Figure 1. Schematic diagram of the Penouta open pit sample preparation. C, concentrate sample, $\mathrm{T}$, tailing.

\subsection{Analytical Methods}

The whole rock sample and the $\mathrm{Sn}, \mathrm{Ta}, \mathrm{Nb}, \mathrm{U}$, and $\mathrm{Th}$ of all the grinding products were analyzed at ALS laboratories by X-ray fluorescence (XRF) using glass beads, followed by acid digestion and Inductively Coupled Plasma Mass Spectrometry (ICP-MS). 
Mineralogy was determined by optical microscopy, X-ray powder diffraction (XRD), scanning electron microscopy with energy-dispersive spectral analysis (SEM-EDS) in the back-scattered electron mode (BSE), and EMPA. Electron microprobe analyses were obtained in a JEOL JXA-8230 electron microprobe. X-ray diffraction data were collected with a PANanalytical X'Pert PRO MPD X-ray diffractometer at the Centres Cientifics i Tecnologics de la Universitat de Barcelona. Identification and Rietveld semiquantitative evaluation of phases were made on PANanalytical X'Pert HighScore software. Scanning electron microscopy with SEM-EDS was used in the BSE mode.

A JEOL JXA-8230 EMPA located at the Centres Cientifics i Tecnològics de la Universitat de Barcelona was used to obtain the chemistry of minerals. More than 500 analyses on $\mathrm{Nb}$-Ta-rich minerals were conducted at an accelerating voltage of $20 \mathrm{kV}$, an electron beam current of $20 \mathrm{nA}$, and a beam diameter of $2 \mu \mathrm{m}$. Each element was counted for $5 \mathrm{~s}$, except Ti, Sc, and $\mathrm{Pb}$, which were counted for $10 \mathrm{~s}$ and $\mathrm{F}$ for $15 \mathrm{~s}$. Standards used were: $\mathrm{Nb}(\mathrm{NbL} \alpha), \mathrm{Ta}(\mathrm{TaL} \alpha), \mathrm{Fe}_{2} \mathrm{O}_{3}(\mathrm{FeK} \alpha)$, rhodonite $(\mathrm{MnK} \alpha)$, rutile (TiK $\alpha), \mathrm{ThO}_{2}(\mathrm{ThM} \alpha), \mathrm{UO}_{2}(\mathrm{UM} \beta), \mathrm{Sn}(\mathrm{SnL} \alpha), \mathrm{W}(\mathrm{WL} \alpha), \mathrm{Sc}(\mathrm{ScK} \alpha)$, albite $(\mathrm{NaK} \alpha)$, apatite $(\mathrm{FK} \alpha)$, and wollastonite $(\mathrm{CaK} \alpha)$. The detection limits are $0.17 \mathrm{wt} \% \mathrm{U} ; 0.1 \% \mathrm{wt}$. Th and $\mathrm{W} ; 0.06 \mathrm{wt} \% \mathrm{Ta}$, Sn and $\mathrm{Nb}$; and $<0.03 \mathrm{wt} \%$ for other elements. The formulas for columbite-group minerals (CGM) were calculated on the basis of 24 atoms of oxygen and 12 cations. The excess of cations was compensated by recasting $\mathrm{FeO}$ to $\mathrm{Fe}_{2} \mathrm{O}_{3}$ [35].

Automated mineral liberation analysis was used to quantify the mineralogical characteristics of particles and grains. Samples from all the concentrates obtained from HPGR and BM were analyzed using a new generation of the Tescan Integrated Mineralogical Analyzer (TIMA-X). All samples were micro-riffled to produce a representative subsample to be mounted and polished for TIMA-X analysis. Samples were prepared with an addition of graphite flakes. Perpendicular cross-sections through the mounts were created once the epoxy was cured. The cross-sections were remounted in order to avoid the effect of heavy particle settling. It was carried out at the Tescan facilities in Brno, Czech Republic. Measurements were performed using an acceleration voltage of $25 \mathrm{kV}$ and a current of $7.47 \mathrm{nA}$. Dot mapping analytical mode was used for the analysis. The image was segmented in two stages using this approach. The BSE imaging based segmentation with a resolution of $2 \mu \mathrm{m}$ and preceded the actual collection of EDS spectra. The EDS analytical points (3000 counts) were placed in the middle of each segment smaller than the predefined distance of $10 \mu \mathrm{m}$. Segments larger than this value were covered with a regular mesh of analytical points $10 \mu \mathrm{m}$ apart. Segment boundaries were adjusted based on the chemical information obtained by EDS in the next stage of segmentation.

\section{Results and Discussion}

\subsection{Chemical and Mineralogical Characterization of the Bulk Sample}

The Penouta leucogranite from the open pit area shows a range from 81 to $140 \mathrm{ppm}$ Ta and 50 to $64 \mathrm{ppm}$ of $\mathrm{Nb}$ [35]. The sample used in this study has between $103 \mathrm{ppm}$ of Ta, $81 \mathrm{ppm}$ of Nb, $383 \mathrm{ppm}$ of Sn, and $35 \mathrm{ppm}$ of W. Radioactive elements are present in small amounts, $2.40 \mathrm{ppm}$ of Th and $2.48 \mathrm{ppm}$ of $\mathrm{U}$.

Textural characteristics of tantalum ore from granitic rocks are usually important for process planning. The texture of the rocks and the characteristic texture of the CGM (columbite-tantalite) will define the behavior of this material during comminution.

The inequigranular texture of the Penouta granitic rock is due to the presence of relatively large grains of quartz, $1-2 \mathrm{~mm}$ in size, included in a matrix of other grains lower than $0.5 \mathrm{~mm}$. These are constituted by albite, quartz, K-feldspar (microcline), albite, and muscovite, with minor amounts of kaolinite, garnet (spessartine), tourmaline of schorl type, biotite, zircon, monazite, beryl, cassiterite, and $\mathrm{Nb}$-Ta oxide minerals.

A detailed characterization of $\mathrm{Nb}$-Ta oxide minerals from Penouta is presented in [33-35]. $\mathrm{Nb}$ and Ta occur mainly in minerals of CGM. This group is constituted by a solid solution of columbite and tantalite, with a general formula of $(\mathrm{Fe}, \mathrm{Mn})(\mathrm{Nb}, \mathrm{Ta})_{2} \mathrm{O}_{6}$ and four end members: columbite-( $\left.\mathrm{Fe}\right)$, 
$\mathrm{FeNb}_{2} \mathrm{O}_{6}$; columbite-(Mn), $\mathrm{MnNb}_{2} \mathrm{O}_{6}$; tantalite-(Fe), $\mathrm{FeTa}_{2} \mathrm{O}_{6}$; and tantalite-(Mn), $\mathrm{MnTa}_{2} \mathrm{O}_{6}$. The EMPA data of the ore used in the experiments indicates that these minerals are predominantly columbite-(Mn) and tantalite-(Mn), (Figure 2 and Table 1).

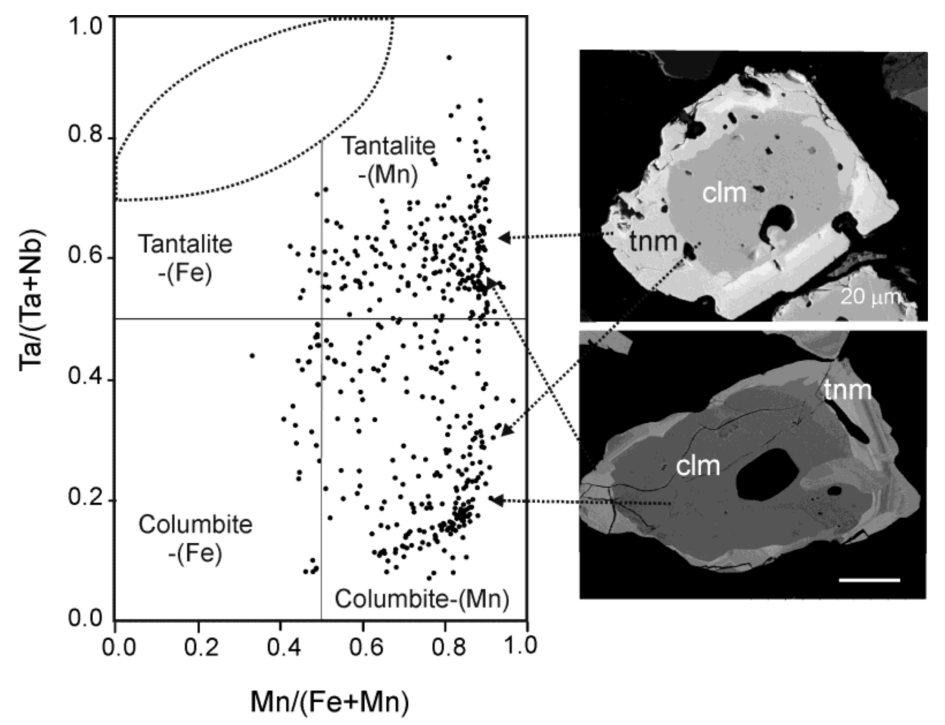

Figure 2. Chemical composition of columbite-group minerals (CGM) from the Penouta open pit in the columbite quadrilateral [35] and two illustrative scanning electron microscopy (SEM) images. Clm, columbite-(Mn); tnm, tantalite-(Mn).

CGM usually occur as grains of less than $250 \mu \mathrm{m}$ with variable composition, consisting of tantalite and columbite distributed in the same grain following different patterns. The most common textural pattern is presented as grains with a $\mathrm{Nb}$-rich core and a Ta-rich rim (Figures 2 and 3).
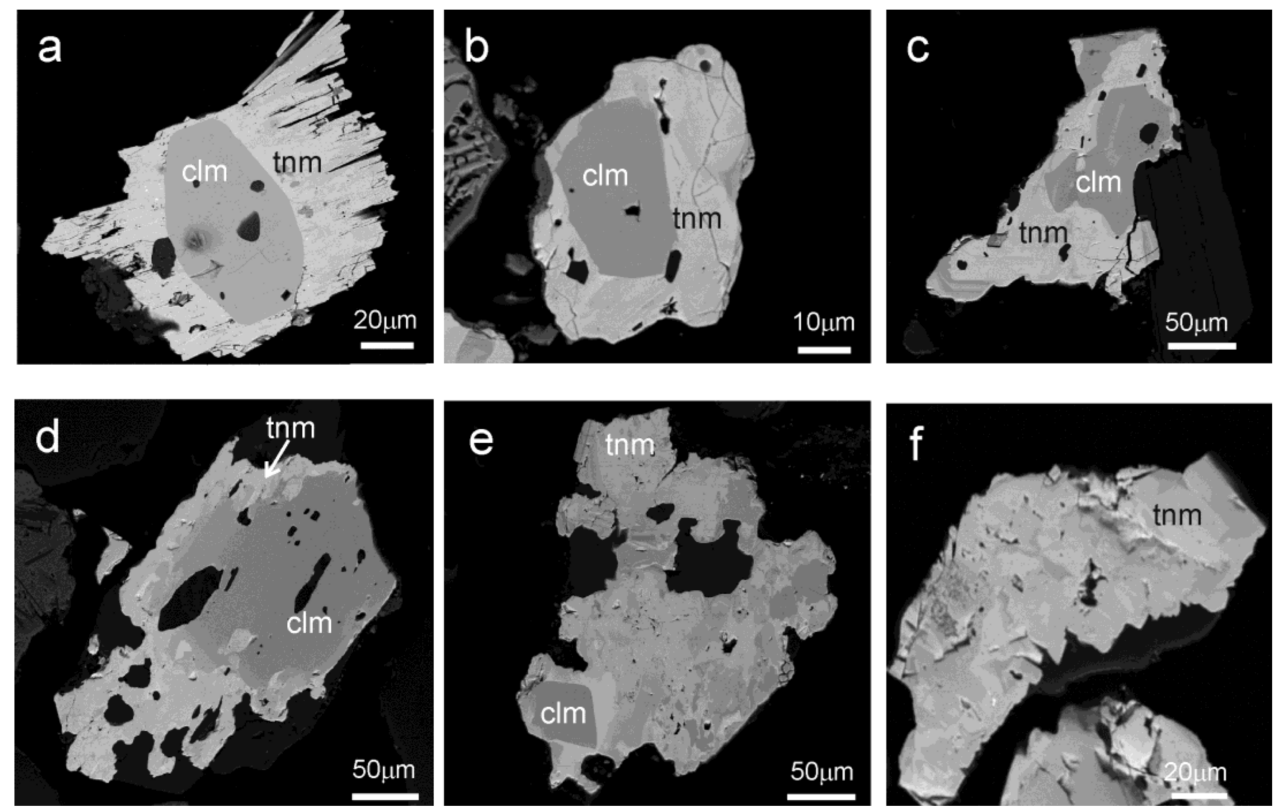

Figure 3. CGM from the Penouta open pit leucogranite showing different textures: (a-d), concentric zoning; (e,f), patchy zoning. Dark grey, columbite-(Mn); bright grey, tantalite-(Mn). 
Microlite-group minerals, $(\mathrm{Ca}, \mathrm{Na}, \mathrm{REE}, \mathrm{U}, \mathrm{Y},)_{2}(\mathrm{Ta}, \mathrm{Nb})_{2} \mathrm{O}_{6}(\mathrm{O}, \mathrm{OH})$, are generally present in Penouta as crystals a few microns in size and are associated with columbite-tantalite (Figure 4a). The chemical composition is highly variable. Although $\mathrm{Ca}$ (being classified as oxymicrolite) is the most abundant cation in Penouta, in some cases, $\mathrm{U}$ and $\mathrm{Pb}$ contents are also abundant, and kenoplumbomicrolite occasionally occurs as rims around microlite. Wodginite, $(\mathrm{Ta}, \mathrm{Nb}, \mathrm{Sn}, \mathrm{Mn}, \mathrm{Fe})_{4} \mathrm{O}_{8}$, is present in minor amounts. Under the SEM, it has a grey color that can only be determined with the EDS due to its high content in both Ta and Sn (Figure 4b).
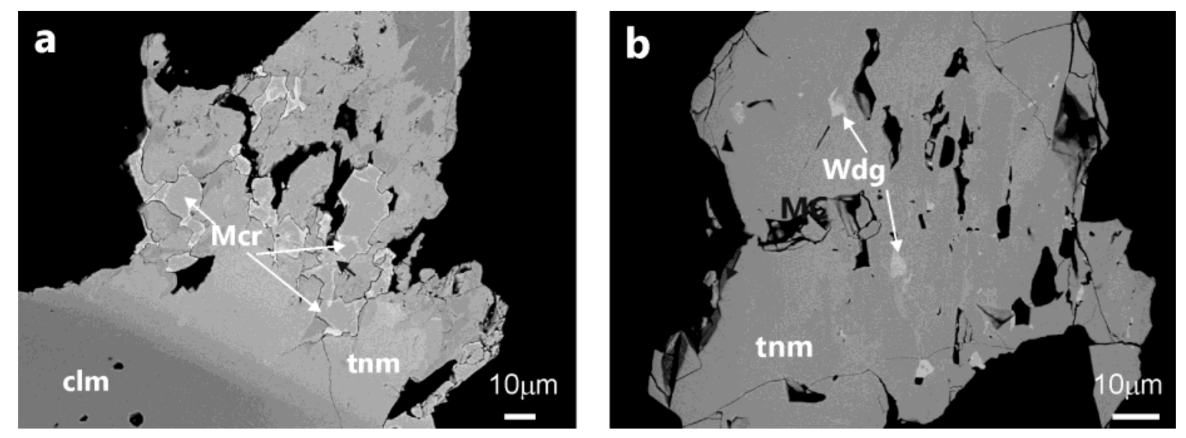

Figure 4. Microlite (a) and wodginite (b) from the Penouta open pit leucogranite. Mcr, microlite; Wdg, wodginite. clm, columbite-(Mn); tnm, tantalite-(Mn).

Cassiterite is the most abundant ore mineral in Penouta, and it occurs as homogeneous subhedral to anhedral grains. The chemical composition shows a high Ta content, up to 9 wt $\%$ of $\mathrm{Ta}_{2} \mathrm{O}_{5}$.

Table 1. Representative chemical composition of CGM from the Penouta open pit.

\begin{tabular}{|c|c|c|c|c|c|c|c|c|}
\hline Oxides, wt \% & P1 & $\mathbf{P} 2$ & P3 & P94 & P5 & P6 & P7 & P8 \\
\hline & $\mathrm{clm}$ & $\mathrm{clm}$ & clf & $\mathrm{clm}$ & tnm & tnm & tnm & tnm \\
\hline $\mathrm{WO}_{3}$ & 0.23 & 0.11 & 0.52 & 0.33 & 0.19 & 0.16 & 0.33 & 0.43 \\
\hline $\mathrm{Ta}_{2} \mathrm{O}_{5}$ & 19.13 & 20.47 & 30.22 & 47.29 & 55.80 & 57.69 & 63.55 & 69.87 \\
\hline $\mathrm{Nb}_{2} \mathrm{O}_{5}$ & 61.06 & 60.17 & 50.46 & 33.87 & 27.33 & 24.21 & 19.52 & 13.57 \\
\hline $\mathrm{TiO}_{2}$ & 0.04 & 0.02 & 0.06 & 0.10 & 0.00 & 0.09 & 0.12 & 0.00 \\
\hline $\mathrm{UO}_{2}$ & 0.00 & 0.02 & 0.00 & 0.31 & 0.04 & 0.24 & 0.00 & 0.11 \\
\hline $\mathrm{ThO}_{2}$ & 0.00 & 0.00 & 0.00 & 0.22 & 0.00 & 0.00 & 0.08 & 0.00 \\
\hline $\mathrm{Sc}_{2} \mathrm{O}_{3}$ & 0.14 & 0.16 & 0.07 & 0.01 & 0.08 & 0.37 & 0.30 & 0.01 \\
\hline $\mathrm{SnO}_{2}$ & 0.06 & 0.08 & 0.10 & 0.11 & 0.18 & 0.22 & 0.22 & 0.24 \\
\hline $\mathrm{Fe}_{2} \mathrm{O}_{3}$ & 0.52 & 0.34 & 0.14 & 1.12 & 0.29 & 1.28 & 0.71 & 0.34 \\
\hline $\mathrm{FeO}$ & 2.86 & 3.07 & 9.80 & 7.74 & 1.63 & 2.14 & 7.55 & 3.38 \\
\hline $\mathrm{MnO}$ & 16.35 & 16.16 & 8.68 & 8.53 & 14.48 & 12.98 & 7.65 & 11.36 \\
\hline \multirow[t]{2}{*}{ Total } & 100.41 & 100.60 & 100.05 & 99.65 & 100.02 & 99.38 & 100.03 & 99.31 \\
\hline & \multicolumn{8}{|c|}{ Atomic Contents } \\
\hline $\mathrm{W}^{6+}$ & 0.015 & 0.007 & 0.034 & 0.024 & 0.015 & 0.012 & 0.025 & 0.035 \\
\hline $\mathrm{Ta}^{5+}$ & 1.259 & 1.352 & 2.099 & 3.580 & 4.374 & 4.603 & 5.195 & 5.972 \\
\hline $\mathrm{Nb}^{5+}$ & 6.673 & 6.599 & 5.827 & 4.263 & 3.560 & 3.211 & 2.653 & 1.928 \\
\hline $\mathrm{Ti}^{2+}$ & 0.007 & 0.003 & 0.011 & 0.022 & 0.000 & 0.021 & 0.028 & 0.000 \\
\hline $\mathrm{U}^{4+}$ & 0.000 & 0.001 & 0.000 & 0.019 & 0.003 & 0.016 & 0.000 & 0.008 \\
\hline $\mathrm{Th}^{4+}$ & 0.000 & 0.000 & 0.000 & 0.014 & 0.000 & 0.000 & 0.006 & 0.000 \\
\hline $\mathrm{Sc}^{3+}$ & 0.012 & 0.016 & 0.022 & 0.028 & 0.046 & 0.055 & 0.058 & 0.065 \\
\hline $\mathrm{Sn}^{4+}$ & 0.015 & 0.017 & 0.008 & 0.001 & 0.011 & 0.048 & 0.040 & 0.000 \\
\hline $\mathrm{Fe}^{3+}$ & 0.095 & 0.062 & 0.027 & 0.235 & 0.063 & 0.285 & 0.149 & 0.080 \\
\hline $\mathrm{Fe}^{2+}$ & 0.577 & 0.622 & 2.094 & 1.803 & 0.393 & 0.523 & 1.898 & 0.888 \\
\hline $\mathrm{Mn}^{2+}$ & 3.347 & 3.321 & 1.878 & 2.011 & 3.535 & 3.226 & 1.948 & 3.024 \\
\hline CATSUM & 12.000 & 12.000 & 12.000 & 12.000 & 12.000 & 12.000 & 12.000 & 12.000 \\
\hline
\end{tabular}




\subsection{Characterization of the Comminuted Products}

\subsubsection{Particle Size Distribution (PSD)}

The particle size distributions obtained after grinding using HPGR and a BM, or only a BM, are similar (Figure 5). After the HPGR grinding $40 \mathrm{wt} \%$ of the material is smaller than $600 \mu \mathrm{m}$. From this, $31.8 \mathrm{wt} \%$ is lower than $250 \mu \mathrm{m}$, and $8.8 \mathrm{wt} \%$ is in the range $250-600 \mu \mathrm{m}$. Finally, only $11 \mathrm{wt} \%$ of the material is coarser than $600 \mu \mathrm{m}$. In the BM product, $22.8 \mathrm{wt} \%$ of processed material is higher than $600 \mu \mathrm{m}$, and about $61 \mathrm{wt} \%$ is lower than $250 \mu \mathrm{m}$. According to Reference [38], when the HPGR unit was in an open circuit together with a BM, it had no significant effect on the fineness of the final comminuted product. However, in the present investigation, the BM combined with a previous step of HPGR produces a finer end product than with the BM alone.

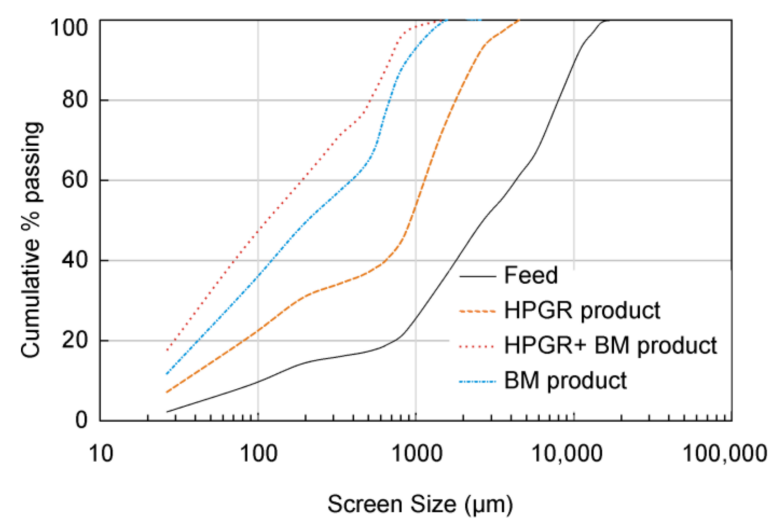

Figure 5. Particle size distribution curves for the feed and ground products.

\subsubsection{Modal Mineralogy}

The modal mineralogy of concentrates from the open pit of Penouta was determined by TIMA-X (Figure 6), and the composition of the resulting tailings was obtained by XRD. The combination of both techniques is useful to obtain a complete mineralogical characterization. X-ray powder diffusion ensures representativeness in coarse-grained samples, because it measures millions of particles as a result of grinding the sample to less than $60 \mu \mathrm{m}$. However, this technique can only detect minerals in concentrations over $1 \mathrm{wt} \%$ [39]. Thus, these techniques are complementary, and often the combination of both is necessary to obtain satisfactory results.

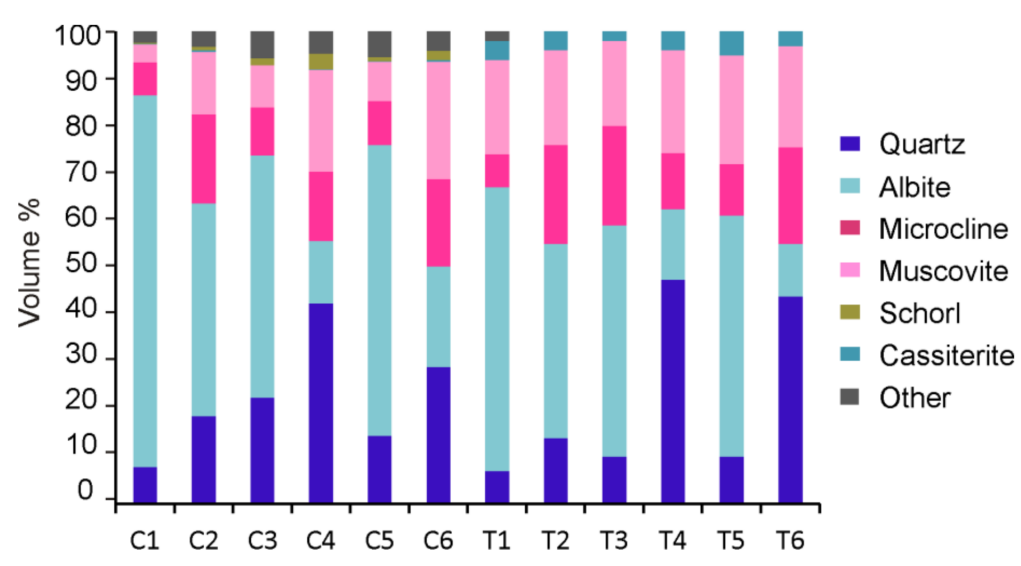

Figure 6. Modal mineralogy of the grinding products. C1 to C6 are the concentrates analyzed by a Tescan Integrated Mineralogical Analyzer (TIMA-X) and in tailings (T1-T6) determined by X-ray powder diffraction (XRD). 
Albite is the most abundant mineral in all fractions of $-250 \mu \mathrm{m}$, whereas quartz is dominant in concentrates from the coarser fractions of the final processes (C4 and C6) and the equivalent ratios in tailings (T4 and T6). K-feldspar is microcline, as indicated by the XRD data and by the presence of the grid twining. This mineral occurs in variable amounts, being more abundant in concentrate products of coarser size, with $7-10 \mathrm{wt} \%$ in products of a size less than $250 \mu \mathrm{m}$, and $15-50 \mathrm{wt} \%$ in products between 250 and $600 \mu \mathrm{m}$.

Optical and XRD allowed determining that K-feldspar is microcline. This is homogeneously distributed, except in the fraction of $-250 \mu \mathrm{m}$ obtained from HPGR processing, which has a lower content.

Muscovite content is considerably different in concentrates and tailings. The most significant difference between the mineralogical data obtained from TIMA-X and XRD is the amount of muscovite. The sheet structure of this mineral makes quantification difficult in the analysis of sections and also in XRD estimations. Muscovite is usually overestimated in XRD analyses due to the preferential orientation of crystals [40]. Other studies also found discrepancies in the content of micas between the results provided by both techniques [41].

Minor minerals have been included in Figure 6 as are other minerals. These are mainly beryl, phosphates, such as apatite, xenotime, and monazite, and scheelite, pyrite, hematite, and ilmenite.

The composition of minerals in tailings after the gravity concentration of $\mathrm{Nb}$-Ta minerals is presented in Table 2. Albite is the most abundant mineral in the tailing products finer than $250 \mu \mathrm{m}$, whereas quartz is predominant in products of $+600 \mu \mathrm{m}$ (T7 and T8) and in the size fraction of 250-600 $\mu \mathrm{m}$ that was not grinded with HPGR. Although the obtained quartz contents were higher in the tailings, they vary proportionally with those from the respective concentrates.

Table 2. Semi-quantitative mineral composition of the product tailings determined by XRD. Particle size of T1, T3, and T5 is $-250 \mu \mathrm{m} ; \mathrm{T} 2, \mathrm{~T} 4$ and T6 is $250-600 \mu \mathrm{m}$; and T7 and T8 is $+600 \mu \mathrm{m}$.

\begin{tabular}{ccccccccc}
\hline Mineral (wt \%) & T1 & T2 & T3 & T4 & T5 & T6 & T7 & T8 \\
\hline Quartz & 7 & 14 & 10 & 48 & 10 & 43 & 62 & 37 \\
Albite & 60 & 41 & 51 & 15 & 51 & 11 & 15 & 30 \\
Microcline & 7 & 21 & 23 & 12 & 11 & 20 & 13 & 14 \\
Muscovite & 20 & 20 & 14 & 22 & 23 & 21 & 7 & 16 \\
Kaolinite & 4 & 4 & 2 & 4 & 5 & 3 & 1 & 1 \\
Beryl & 2 & & - & - & - & - & - & 2 \\
\hline
\end{tabular}

\subsubsection{Morphology and Texture of Particles}

The mineral composition maps of the $\mathrm{Nb}$-Ta rich minerals (Figure 7) show their morphology and mineral association. Although columbite and tantalite are usually present in the same particle, tantalite occurs in particles smaller than those of columbite. This is also partly evident in the images due to a possible stereological error.

An essential parameter for mineral processing is the shape of ground particles and this can be influenced by the methods used for comminution [42]. HPGR produce a higher surface area in minerals than other comminution devices, such as jaw crushers [43]. In Penouta ore ground using HPGR, particles exhibit higher angularity than those obtained from a BM, as well as a larger specific surface area (Figure 8). 


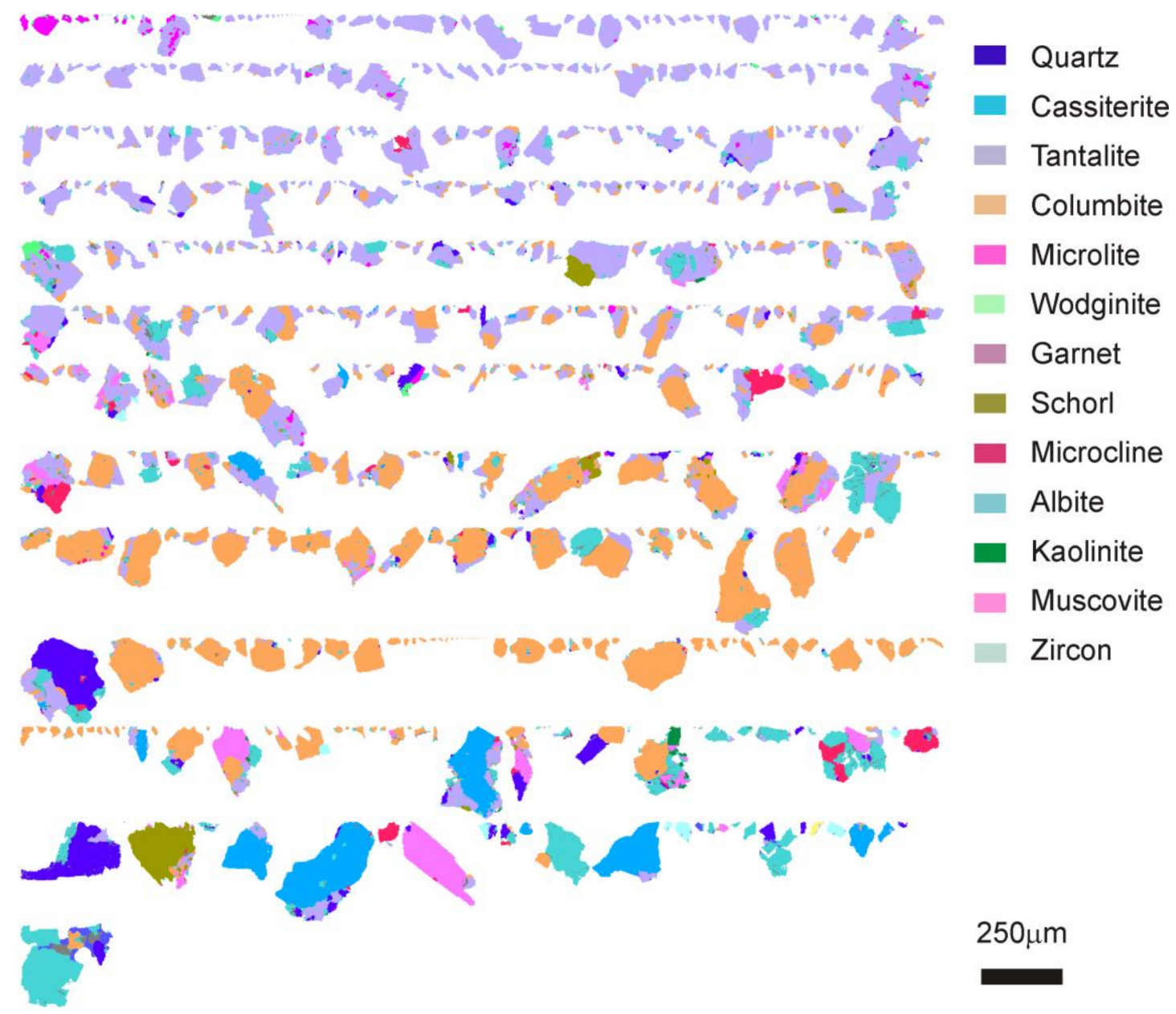

Figure 7. TIMA false color images of columbite-tantalite from concentrates of less than $250 \mu \mathrm{m}$ obtained from ground material using a ball mill (BM).
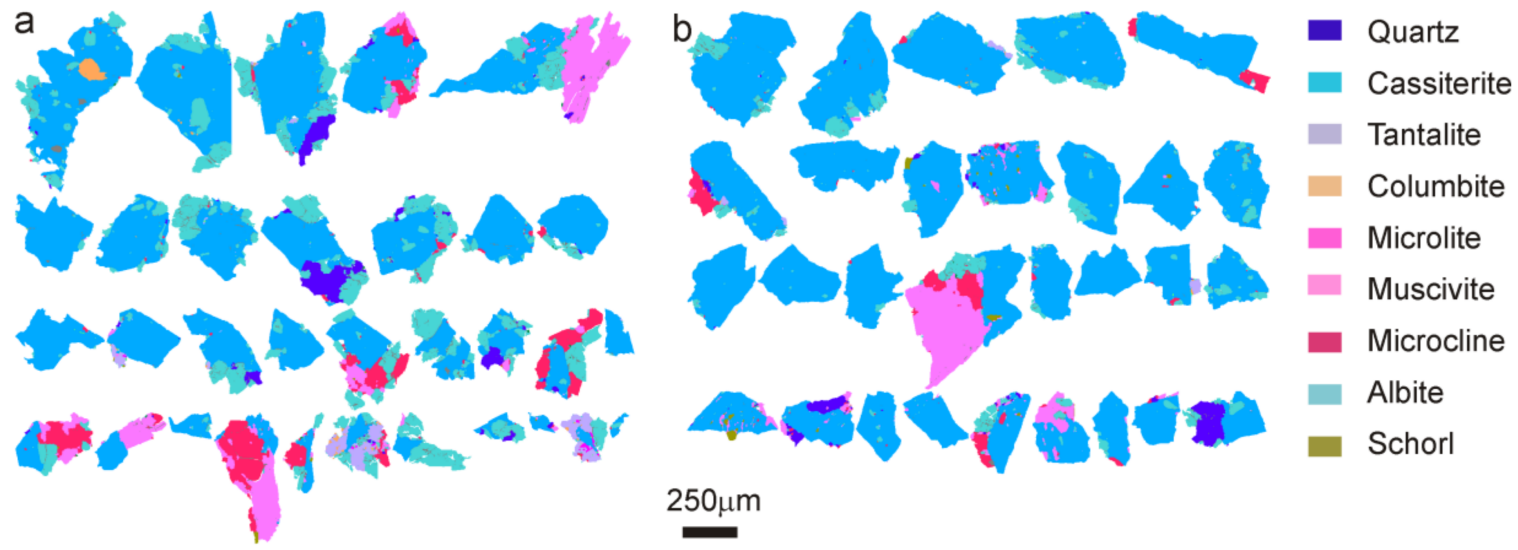

Figure 8. TIMA false color images for shape comparison of cassiterite-rich particles in the 250-600 size fraction obtained (a) with high-pressure grinding rolls (HPGR), and (b) BM. Color legend as in Figure 7.

\subsubsection{Mineral Associations}

CGM grains are mainly associated with albite, quartz, muscovite, and cassiterite (Figure 9). The locking properties of ore from the Penouta open pit are highly dependent on the relationship between the mineral and particle size. The free surface indicates those minerals that are not surrounded 
by others. Free surface is highest in cassiterite compared to other ore minerals (Table 3) due to the higher grain size of this mineral. In CGM, as they often constitute crystals with a columbite core and a tantalite rim, tantalite presents more free surface than columbite. In the case of microlite and wodginite, these minerals are a few microns in size and usually genetically associated with columbite and tantalite [35], and thus, in most cases they are locked in these minerals and also in albite and cassiterite. CGM and cassiterite association occurs mainly in coarse particles, where usually tantalite is in contact with or included in cassiterite.

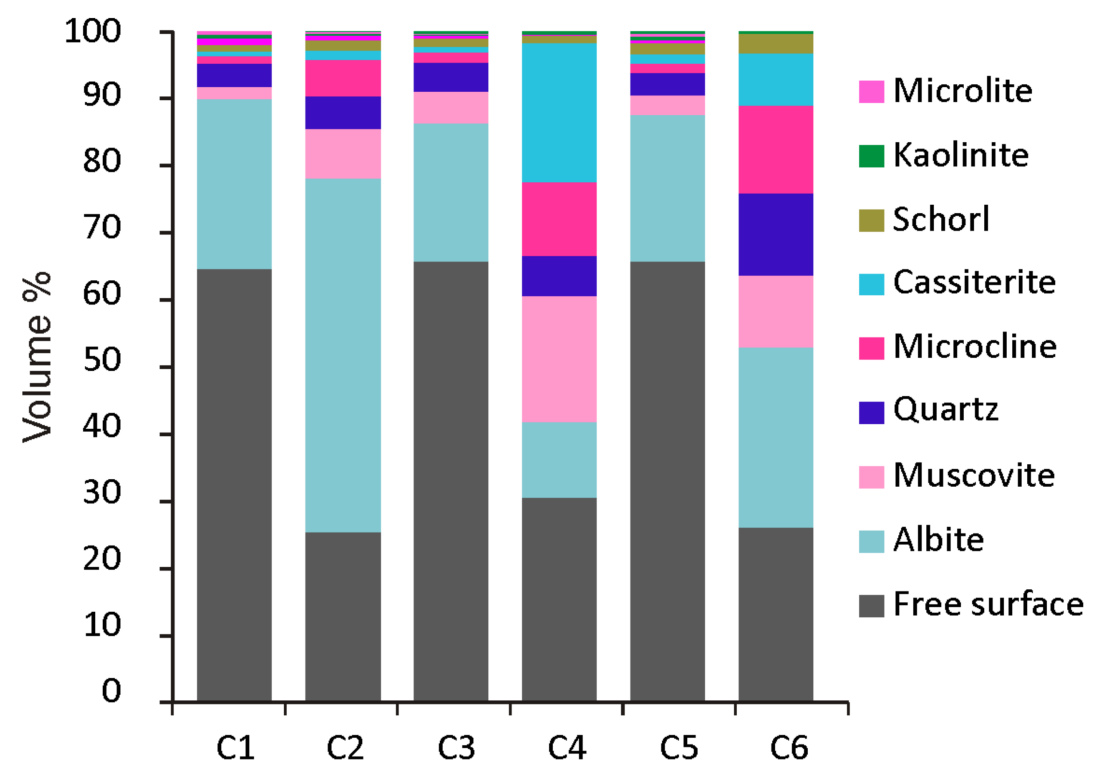

Figure 9. Mineral locking of CGM from the Penouta open pit.

Table 3. Free surface of ore minerals from the Penouta open pit.

\begin{tabular}{ccccccc}
\hline Mineral (wt \%) & C1 & C2 & C3 & C4 & C5 & C6 \\
\hline Cassiterite & 84.06 & 48.55 & 87.97 & 71.05 & 82.38 & 67.66 \\
Columbite & 45.62 & 11.13 & 50.39 & 30.13 & 52.40 & 13.44 \\
Tantalite & 50.45 & 18.66 & 53.59 & 23.65 & 48.19 & 26.17 \\
Microlite & 8.38 & 1.96 & 26.29 & 0.39 & 26.59 & 0.00 \\
Wodginite & 5.72 & 1.07 & 11.66 & 0.18 & 14.20 & 0.43 \\
\hline
\end{tabular}

\subsubsection{Metal Distribution}

The chemical composition of concentrates and tailings obtained in this study are shown in Table 4. $\mathrm{Nb}$ and Ta occur in significant amounts in all particle size fractions obtained in the experiments. After grinding by HPGR, Ta content is similar in both fraction sizes (less and more than $250 \mu \mathrm{m}$ ), whereas with a BM, the smaller fraction is always Ta-richer; Ta-rich minerals move to the concentrate, remaining in the tailing a minor amount. Similar behavior exists for $\mathrm{Nb}$ and $\mathrm{Sn}$. However, in the size fraction of $+250 \mu \mathrm{m}$ higher, contents of $\mathrm{Nb}$-Ta-rich minerals are in the tailings, especially in the case of products obtained from grinding by HPGR, where 80 ppm remain in the tailings. Tailings of product with a size of $+600 \mu \mathrm{m}$ are poor in $\mathrm{Nb}$ and $\mathrm{Ta}$, but still have high Sn contents, 336-528 ppm. 
Table 4. Chemical composition and mineralogy of the grinding products of the Penouta ore. tn, tantalite; cl, columbite, and Cst, cassiterite.

\begin{tabular}{|c|c|c|c|c|c|c|c|c|c|c|c|c|c|c|}
\hline \multirow{3}{*}{$\begin{array}{l}\text { Grinding } \\
\text { Method }\end{array}$} & \multicolumn{6}{|c|}{ Chemical Composition (ppm) } & \multicolumn{8}{|c|}{ Mineralogy (wt \%) } \\
\hline & \multirow[b]{2}{*}{ Size $(\mu \mathrm{m})$} & \multirow[b]{2}{*}{ Sample } & \multirow[b]{2}{*}{ Type } & \multirow[b]{2}{*}{ Sn } & \multirow[b]{2}{*}{$\mathrm{Nb}$} & \multirow[b]{2}{*}{ Ta } & \multicolumn{4}{|c|}{ (Normative) } & \multicolumn{4}{|c|}{ (TIMA-X) } \\
\hline & & & & & & & Cst & tn & cl & $\operatorname{tn} / \mathrm{cl}$ & Cst & tn & cl & $\mathrm{tn} / \mathrm{cl}$ \\
\hline HPGR & -250 & PN-1 & $\mathrm{C} 1$ & 3010 & 1080 & 1980 & 0.38 & 0.28 & 0.23 & 1.22 & 0.39 & 0.72 & 0.24 & 3.07 \\
\hline HPGR & +250 & PN-3 & C2 & - & 1030 & 1990 & - & 0.28 & 0.22 & 1.29 & 1.81 & 0.58 & 0.19 & 3.02 \\
\hline $\mathrm{HPGR}+\mathrm{BM}$ & -250 & PN-5 & $\mathrm{C} 3$ & - & 1435 & 2720 & - & 0.39 & 0.30 & 1.26 & 1.30 & 0.63 & 0.28 & 2.26 \\
\hline $\mathrm{HPGR}+\mathrm{BM}$ & +250 & PN-7 & $\mathrm{C} 4$ & - & 635 & 1355 & - & 0.19 & 0.13 & 1.42 & 3.76 & 0.06 & 0.04 & 1.43 \\
\hline $\mathrm{BM}$ & -250 & PN-9 & C5 & - & 2550 & 5000 & - & 0.71 & 0.54 & 1.31 & 1.99 & 1.13 & 0.58 & 1.96 \\
\hline $\mathrm{BM}$ & +250 & PN-11 & C6 & - & 905 & 1895 & - & 0.27 & 0.19 & 1.40 & 3.23 & 0.11 & 0.07 & 1.68 \\
\hline HPGR & -250 & PN-2 & $\mathrm{T} 1$ & 67 & 14 & 30 & 0.01 & 0.00 & 0.00 & 1.43 & & & & \\
\hline HPGR & +250 & $\mathrm{PN}-4$ & $\mathrm{~T} 2$ & 224 & 58 & 80 & 0.03 & 0.01 & 0.01 & 0.92 & & & & \\
\hline HPGR + BM & -250 & PN-6 & T3 & 88 & 17 & 30 & 0.01 & 0.00 & 0.00 & 1.18 & & & & \\
\hline $\mathrm{HPGR}+\mathrm{BM}$ & +250 & PN-8 & $\mathrm{T} 4$ & 131 & 45 & 40 & 0.02 & 0.01 & 0.01 & 0.59 & & & & \\
\hline $\mathrm{BM}$ & -250 & PN-10 & T5 & 118 & 23 & 40 & 0.01 & 0.01 & 0.00 & 1.16 & & & & \\
\hline $\mathrm{BM}$ & +250 & PN-12 & T6 & 132 & 49 & 50 & 0.02 & 0.01 & 0.01 & 0.68 & & & & \\
\hline HPGR + BM & +600 & PN-19 & T7 & 528 & 42 & 30 & 0.07 & 0.00 & 0.01 & 0.48 & & & & \\
\hline $\mathrm{BM}$ & +600 & PN-20 & $\mathrm{T} 8$ & 336 & 46 & 60 & 0.04 & 0.01 & 0.01 & 0.87 & & & & \\
\hline
\end{tabular}


The mineral content of the ore was determined by TIMA, and a theoretical composition was also calculated from the chemical composition data of the different fractions (Table 4). As columbite and tantalite are the main $\mathrm{Ta}-\mathrm{Nb}$ bearing phases, all $\mathrm{Ta}$ was assigned to tantalite and all $\mathrm{Nb}$ is in columbite. The TIMA results show that the most abundant ore mineral in the concentrates is cassiterite, followed by tantalite and columbite, determined by the chemical composition calculated, assuming that all Ta is in tantalite and all $\mathrm{Nb}$ is in columbite. The contents of microlite and wodginite have not been taken into account due to the low significance of their content.

The tantalite/columbite ratio in the calculated minerals ranges between 1.2 and 1.4 in the concentrates and significantly lower in the tailings, especially in tailings of $+600 \mu \mathrm{m}$, where it is from 0.5 to 0.9 . This could be attributed to the fact that in the gravity concentration, tantalite moves more easily to the heavy fraction (density of tantalite-(Mn) is 8.1) than columbite (density of columbite-(Mn) is 5.28 ).

The tantalite contents determined by TIMA are higher, whereas the $\mathrm{Nb}$ contents are similar in both determinations (Figure 10). The tantalite/columbite ratio is double in the cases of the lower particle size. This could be due to the stereological error produced during the analysis of image sections $[29,44]$.

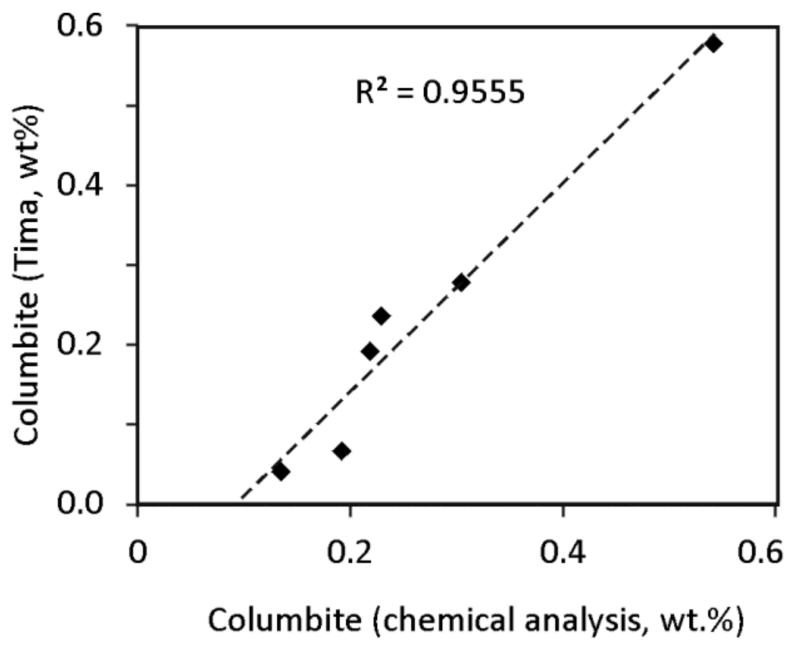

Figure 10. Comparison of the columbite content of the grinding products determined by TIMA and from the chemical composition.

\subsection{Mineral Liberation}

In the present study, the ore is considered as liberated when it represents $>90$ vol $\%$ of the particle volume. The TIMA provided the liberation characteristics of ore from the different steps of the treatment. The degree of columbite-tantalite liberation depends on the particle size (Figure 11). The highest degrees of liberation are achieved in particles smaller than $250 \mu \mathrm{m}$ that have been comminuted with the combination of HPGR and a BM, especially in the case of cassiterite, where $84 \mathrm{wt} \%$ is liberated compared to $69.76 \mathrm{wt} \%$ when only a BM is used (Table 5).

In the fraction less than $250 \mu \mathrm{m}$, about $65 \mathrm{wt} \%$ of the columbite-tantalite minerals are liberated, whereas only $25-30 \mathrm{wt} \%$ is liberated in particles larger than $250 \mu \mathrm{m}$. This is caused by the grain size of CGM, which usually is lower than $200 \mu \mathrm{m}$.

However, in sizes between 250 and $600 \mu \mathrm{m}$, greater degrees of liberation occur in the products obtained from BM grinding. As Figure 11 shows, this is due to the low liberation degree achieved with HPGR. Therefore, all products larger than $250 \mathrm{~m}$ obtained from this milling should be treated with a BM. 


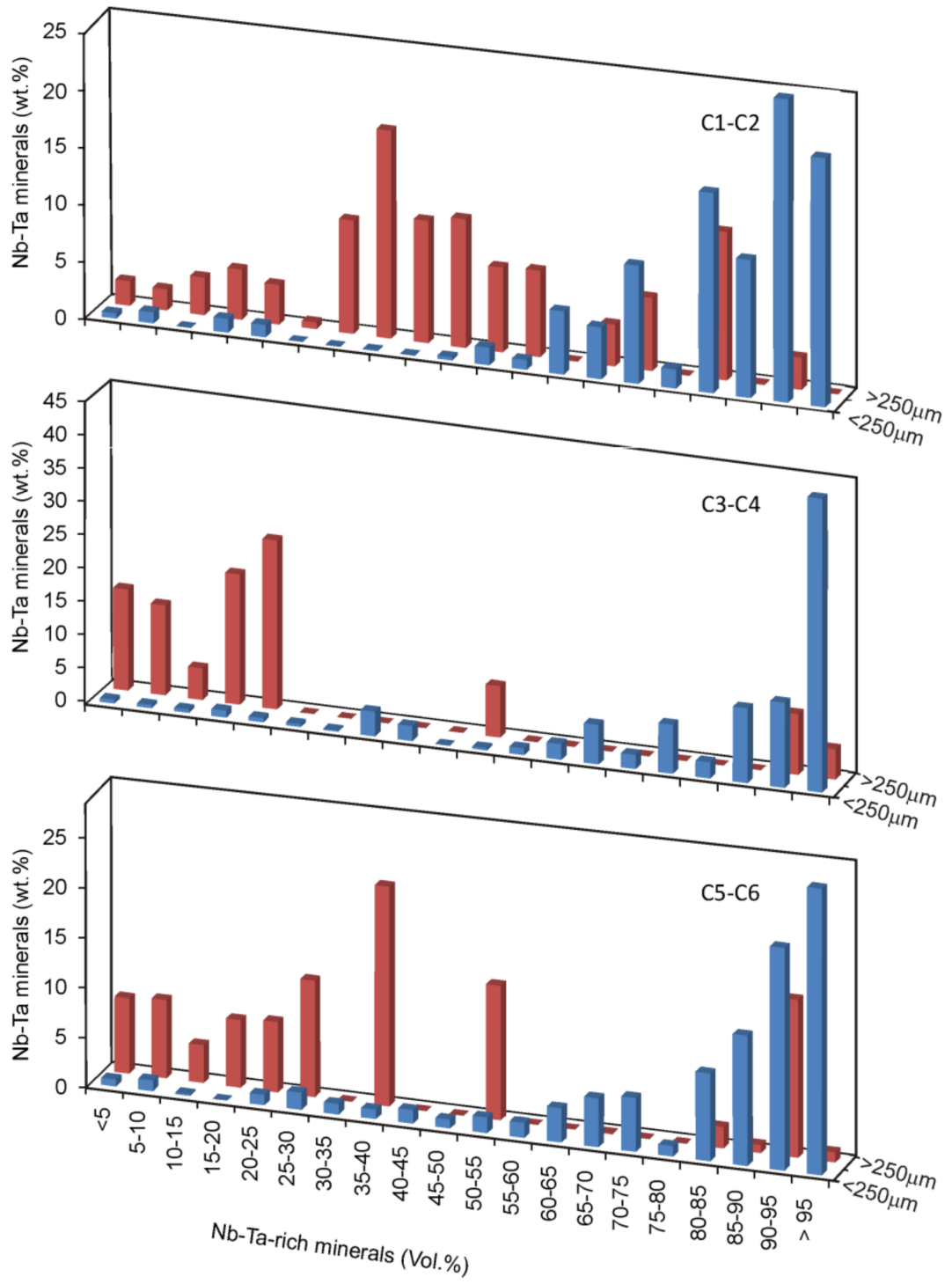

Figure 11. Distribution of the Nb-Ta-rich minerals in the concentrate material from the Penouta open pit according to particle size and grade classes.

Table 5. Liberation of cassiterite and CGM from the Penouta open pit leucogranite. Grade is reported in volume $\%$ and minerals content in wt \%.

\begin{tabular}{ccccccccc}
\hline Mineral & \multicolumn{3}{c}{ Casssiterite } & \multicolumn{3}{c}{ Columbite-Group } \\
\hline & HPGR + BM & \multicolumn{2}{c}{ BM } & \multicolumn{2}{c}{ HPGR + BM } & \multicolumn{3}{c}{ BM } \\
\hline Grade & $\mathbf{- 2 5 0}$ & $\mathbf{+ 2 5 0}$ & $\mathbf{- 2 5 0}$ & $\mathbf{+ 2 5 0}$ & $\mathbf{- 2 5 0}$ & $\mathbf{+ 2 5 0}$ & $\mathbf{- 2 5 0}$ & $\mathbf{+ 2 5 0}$ \\
\hline$<10$ & 0.08 & 0.14 & 0.10 & 0.16 & 1.20 & 17.51 & 1.79 & 15.37 \\
$10-20$ & 0.00 & 0.79 & 0.00 & 0.00 & 1.39 & 16.64 & 0.18 & 10.56 \\
$20-30$ & 0.44 & 1.79 & 0.55 & 4.14 & 1.07 & 15.66 & 2.79 & 18.68 \\
$30-40$ & 0.00 & 3.96 & 0.88 & 1.86 & 2.25 & 11.83 & 2.06 & 22.01 \\
$40-50$ & 0.11 & 4.84 & 1.96 & 2.46 & 1.43 & 9.24 & 2.30 & 0.00 \\
$50-60$ & 0.34 & 4.38 & 0.63 & 0.56 & 1.77 & 10.58 & 3.10 & 13.48 \\
$60-70$ & 3.53 & 16.02 & 5.42 & 8.40 & 8.85 & 1.57 & 8.37 & 0.10 \\
$70-80$ & 7.35 & 16.76 & 2.71 & 4.23 & 10.32 & 2.70 & 6.49 & 0.00 \\
$80-90$ & 4.21 & 22.74 & 17.98 & 40.83 & 19.82 & 5.51 & 21.88 & 2.97 \\
$>90$ & 83.95 & 28.59 & 69.76 & 37.36 & 51.90 & 8.76 & 51.04 & 16.83 \\
\hline
\end{tabular}


The gravity concentration was effective in the case of liberated and $\mathrm{Nb}$-Ta-rich particles, which are mainly in the fraction lower than $250 \mu \mathrm{m}$; however, particles rich in gangue minerals, which usually have a density lower than 3 , go to the tailings product. This is more significant in the case of HPGR products of $250-600 \mu \mathrm{m}$, where $61 \mathrm{wt} \%$ of the CGM from this fraction are mixed particles between 30 and $60 \mathrm{vol} \%$ of $\mathrm{Nb}$-Ta minerals (Figure 11), which prevents the concentration and causes enrichment in the tailing.

\section{Conclusions}

The Sn-Ta ore from the leucogranite Penouta is mainly constituted in cassiterite and CGM, and also occur as minor contents in microlite and wodginite. The mineral association of the ore minerals depends on the particle size of the ground products. Albite is the most abundant mineral in products of fine particle size, whereas quartz concentrates in the coarser sizes, being the most abundant mineral in tailings of $+600 \mu \mathrm{m}$.

The quantitative process mineralogy was essential to design the comminution method for a tantalum-poor ore. The use of HPGR, followed by a BM, generated a higher proportion of fines, and thus, a higher amount of liberated ore minerals. Grinding products obtained with both HPGR and a $\mathrm{BM}$ produced a high liberation degree in cassiterite, tantalite, and columbite in the fraction of particles of $-250 \mu \mathrm{m}$, but low in the fraction of coarser particles. This is attributed to the small grain size of the ore grains.

Product tailings of a $-250 \mu \mathrm{m}$ size have a low metal content, whereas those between 250 and $600 \mu \mathrm{m}$ are still rich in metals because they are under the liberation size of Na-Ta-rich minerals.

The finest HPGR products can be directly used for gravity or other separation methods, whereas the fraction higher than $250 \mu \mathrm{m}$ should be ground more to liberate the Ta ore and obtain a good recovery.

Acknowledgments: This work is part of the OptimOre project. This project has received funding from the European Union's Horizon 2020 research and innovation programme under grant agreement No. 642201. The research is supported by the SGR-198 and SGR-707 of the Generalitat de Catalunya. The Strategic Minerals enterprise helped in the sampling of Penouta. The Tescan staff from Spain (Ana Pérez Campos and Juan Gabriel Rodriguez) are acknowledge helping in the TIMA analyses. X. Llovet by assisted in the EMPA analyses. Two anonymous reviewers are thanked for helping to improve the manuscript.

Author Contributions: S.A.H. and P.A. designed and performed the experiments, analyzed the data, and wrote the paper; H.A. was responsible of the HPGR experiments and reviewed the manuscript; E.G. was responsible of the Ball mill experiments; J.O. critically reviewed the experimental design, the analysis of the results, and conclusions; Marek Dosbaba carried out the TIMA analyses; M.G.-V. performed the XRD data; and M.C. assisted with the gravity concentration. All authors contributed to data interpretation and discussion.

Conflicts of Interest: The authors declare no conflict of interest.

\section{References}

1. Deetman, S.; van Oers, L.; van der Voet, E.; Tukker, A. Deriving European tantalum flows using trade and production statistics. J. Ind. Ecol. 2017, 22, 166-179. [CrossRef]

2. Linnen, R.L.; Van Lichtervelde, M.; Černý, P. Granitic pegmatites as sources of strategic metals. Elements 2012, 8, 275-280. [CrossRef]

3. Mackay, D.A.R.; Simandl, G.J. Geology, market and supply chain of niobium and tantalum-A review. Miner. Deposita 2014, 49, 1025-1047. [CrossRef]

4. Chakhmouradian, A.R.; Smith, M.P.; Kynicky, J. From "strategic" tungsten to "green" neodymium: A century of critical metals at a glance. Ore Geol. Rev. 2015, 64, 455-458. [CrossRef]

5. European Comission. Study on the Review of the List of Critical Raw Materials. 2017. Available online: https: / publications.europa.eu/en/publication-detail/- / publication/08fdab5f-9766-11e7b92d-01aa75ed71a1/language-en (accessed on 9 February 2018).

6. Černý, P.; Blevin, P.L.; Cuney, M.; London, D. Granite-related ore deposits. In Economic Geology 100th Anniversary Volume; Hedenquist, J.W., Thompson, J.F.H., Goldfarb, R.J., Richards, J.P., Eds.; Society of Economic Geologists: Littleton, CO, USA, 2005; pp. 337-370. 
7. Wikedzi, A.; Arinanda, M.A.; Leißner, T.; Peuker, U.A.; Mütze, T. Breakage and liberation characteristics of low grade sulphide gold ore blends. Miner. Eng. 2018, 115, 33-40. [CrossRef]

8. Morrell, S. A method for predicting the specific energy requirement of comminution circuits and assessing their energy utilisation efficiency. Miner. Eng. 2008, 2, 224-233. [CrossRef]

9. Aydoğan, N.A.; Benzer, H. Comparison of the overall circuit performance in the cement industry: High compression milling vs. ball milling technology. Miner. Eng. 2011, 24, 211-215. [CrossRef]

10. Ballantyne, G.R.; Hilden, M.; van der Meer, F.P. Improved characterisation of ball milling energy requirements for HPGR products. Miner. Eng. 2018, 16, 72-81. [CrossRef]

11. Romer, R.L.; Smeds, S.A.; Černý, P. Crystal-chemical and genetic controls of U-Pb systematics of columbite-tantalite. Mineral. Petrol. 1996, 57, 243-260. [CrossRef]

12. Jones, M.P. Applied Mineralogy: A Quantitative Approach; Graham and Trotman: London, UK, 1987.

13. King, R.P. Modelling and Simulation of Mineral Processing Systems; Butterworth-Heinemann: New Delhi, India, 2001; ISBN 0-7506-4884-8.

14. Little, L.; Becker, M.; Wiese, J.; Mainza, A.N. Auto-SEM particle shape characterisation: Investigating fine grinding of UG2 ore. Miner. Eng. 2015, 82, 92-100. [CrossRef]

15. Gaudin, A.M. Principles of Mineral Dressing; McGraw-Hill: New York, NY, USA, 1939.

16. Butcher, A.R. A practical guide to some aspects of mineralogy that affect flotation. In Flotation Plant Optimisation; Spectrum Ser. Greet, C.J., Ed.; The Australasian Institute of Mining and Metallurgy: Melbourne, Australia, 2010; Volume 16, pp. 83-93.

17. Djordjevic, N. Image based modelling of rock fragmentation. Miner. Eng. 2013, 46-47, 68-75. [CrossRef]

18. Van der Wielen, K.P.; Rollinson, G. Texture-based analysis of liberation behaviour using Voronoi tessellations. Miner. Eng. 2016, 89, 93-107. [CrossRef]

19. Schneider, C.L. The Measurement and Calculation of Liberation in Continuous Grinding Circuits. Ph.D. Thesis, University of Utah, Salt Lake City, UT, USA, 1995.

20. Gu, Y. Automated Scanning Electron Microscope Based Mineral Liberation Analysis An Introduction to JKMRC/FEI Mineral Liberation Analyser. J. Miner. Mater. Charact. Eng. 2003, 2, 33-41. [CrossRef]

21. Fandrich, R.; Gu, Y.; Burrows, D.; Moeller, K. Modern SEM-based mineral liberation analysis. Int. J. Miner. Process. 2007, 84, 310-320. [CrossRef]

22. Hunt, J.A.; Berry, R.; Walters, S.G.; Bonnici, N.; Kamenetsky, M.; Nguyen, K.; Evans, C.L. A new look at mineral maps and the potential relationships of extracted data to mineral processing behaviours. In Proceedings of the ICAM Australia 2008, Brisbane, Australia, 8-10 September 2008; pp. 429-432.

23. Ford, F.D.; Wercholaz, C.R.; Lee, A. Predicting process outcomes for Sudbury platinum-group minerals using grade-recovery modelling from Mineral Liberation Analyzer (MLA) data. Can. Mineral. 2011, 49, 1627-1642. [CrossRef]

24. Sandmann, D.; Gutzmer, J. Use of Mineral Liberation Analysis (MLA) in the Characterization of Lithium-Bearing Micas. J. Miner. Mater. Charact. Eng. 2013, 1, 285-292. [CrossRef]

25. Goodall, W.R.; Scales, P.J. An overview of the advantages and disadvantages of the determination of gold mineralogy by automated mineralogy. Miner. Eng. 2007, 116, 82-87. [CrossRef]

26. Cook, N.J.; Ciobanu, C.L.; Ehrig, K.; Slattery, A.; Verdugo-Ihl, M.R.; Courtney-Davies, L.; Gao, W. Advances and opportunities in ore mineralogy. Minerals 2017, 7, 333. [CrossRef]

27. Lotter, N.O. Modern Process Mineralogy: An integrated multi-disciplined approach to flowsheeting. Miner. Eng. 2011, 24, 1229-1237. [CrossRef]

28. Lastra, R.; Paktunc, D. An estimation of the variability in automated quantitative mineralogy measurements through inter-laboratory testing. Miner. Eng. 2016, 95, 138-145. [CrossRef]

29. Spencer, S.; Shutherland, D. Stereological correction of mineral liberation grade distributions estimated by single sectioning of particles. Image Anal. Stereol. 2000, 19, 175-182. [CrossRef]

30. Leißner, T.; Hoang, D.H.; Rudolph, M.; Heing, T.; Bachmann, K.; Gutzmer, J.; Schubert, H.; Peuker, U.A. A mineral liberation study of grain boundary fracture based on measurements of the surface exposure after milling. Int. J. Miner. Process. 2016, 156, 3-13.

31. Shutherland, D. Estimation of mineral grain size using automated mineralogy. Miner. Eng. 2007, 20, 452-460. [CrossRef]

32. ADARO. Proyecto de Investigación de la Mina de Penouta. Cálculo de Reservas Para Leyes de Corte de 800 y 600 g/t; Unpublished Report; 1982; p. 69. 
33. López Moro, F.J.; García Polonio, F.; Llorens González, T.; Sanz Contreras, J.L.; Fernández-Fernández, A.; Moro Benito, M.C. Ta and Sn concentration by muscovite fractionation and degassing in a lens-like granite body: The case study of the Penouta rare-metal albite granite (NW Spain). Ore Geol. Rev. 2017, 82, 10-30. [CrossRef]

34. Llorens González, T.; García Polonio, F.; López Moro, F.J.; Fernández-Fernández, A.; Sans Contreras, J.L.; Moro Benito, M.C. Tin-tantalum-niobium mineralization in the Penouta deposit (NW Spain): Textural features and mineral chemistry to unravel the genesis and evolution of cassiterite and columbite group minerals in a peraluminous system. Ore Geol. Rev. 2017, 81, 79-95. [CrossRef]

35. Alfonso, P.; Hamid, S.; Garcia-Valles, M.; Llorens, T.; López Moro, J.; Tomasa, O.; Calvo, D.; Guasch, E.; Anticoi, H.; Oliva, J.; et al. Textural and mineral-chemistry constraints on columbite-group minerals in the Penouta deposit: Evidence from magmatic and fluid-related processes. Mineral. Mag. 2018. [CrossRef]

36. Ghorbani, Y.; Fitzpatrick, R.; Kinchington, M.; Rollinson, G.; Hegarty, P. A Process Mineralogy Approach to Gravity Concentration of Tantalum Bearing Minerals. Minerals 2017, 7, 194. [CrossRef]

37. Guasch, E.; Anticoi, H.; Hamid, S.A.; Oliva, J.; Alfonso, P.; Escobet, T.; Sanmiquel, L.; Bascompta, M. New approach to ball mill modelling as a piston flow process. Miner. Eng. 2018, 116, 82-87. [CrossRef]

38. Kazerani Nejad, R.; Sam, A. Limitation of HPGR application. Miner. Process. Ext. Met. 2017, 126, $224-230$. [CrossRef]

39. Hill, R.J.; Tsambourakis, G.; Madsen, I.C. Improved petrological modal analyses from X-ray powder diffraction data by use of the rietveld method I. selected igneous, volcanic, and metamorphic rocks. J. Petrol. 1993, 34, 867-900. [CrossRef]

40. Moore, D.M.; Reynolds, R.C. X-ray Diffraction and the Identification and Analysis of Clay Minerals; Oxford University Press: New York, NY, USA, 1989.

41. Rahfeld, A.; Kleeberg, R.; Möckel, R.; Gutzmer, J. Quantitative mineralogical analysis of European Kupferschiefer ore. Miner. Eng. 2018, 115, 21-32. [CrossRef]

42. Vizcarra, T.G.; Wightman, E.M.; Johnson, N.W.; Manlapig, E.V. The effect of breakage mechanism on the mineral liberation properties of sulphide ores. Miner. Eng. 2010, 23, 374-382. [CrossRef]

43. Han, Y.X.; Liu, L.; Yuan, Z.T.; Wang, Z.H.; Zhang, P. Comparison of low-grade hematite product characteristics in a high-pressure grinding roller and jaw crusher. Miner. Metall. Process. 2012, 29, 75-80.

44. Ueda, T.; Oki, T.; Koyaanaka, S. Comparison of Seven Texture Analysis Indices for Their Applicability to Stereological Correction of Mineral Liberation Assessment in Binary Particle Systems. Minerals 2017, 7, 222. [CrossRef] 